\title{
What about Us? - Children's Perspectives on their Wellbeing
}

\section{Perspectivas de los niños y niñas sobre su bienestar}

\section{Perspectiva das crianças sobre o proprio bem- \\ estar}

\author{
Adrijana Visnjic Jevtic \\ ORCID ID: 0000-0003-3812-7472 \\ University of Zagreb, Faculty of Teacher Education, Croacia \\ Ivana Visković \\ ORCID ID: 0000-0002-4029-044X \\ University of Split, Faculty of Humanities and Social Sciences, Croacia \\ Autor referente: adrijana.vjevtic@ufzg.hr \\ Historia editorial: \\ Recibido: 31/01/2021 \\ Aceptado: 09/04/2021
}

\begin{abstract}
The understanding of childhood changes along with the development and changes of society and the social paradigm. Consequently, the child's understanding and acceptance of the role of participation in personal upbringing and education changes, while respecting the child's right to express and respect his/her opinion. This research is aimed at understanding the children's perspective, their subjective experience of current and long-term wellbeing. It was approved by the Ethics Committee of the Faculty of Teacher Education in Zagreb, and implemented in accordance with the Code of Ethics for
\end{abstract}

Research with Children (2003), with the consent of children and their parents. The concept of wellbeing is considered in the dimensions of personal satisfaction, and social and educational achievement. The opinions of 63 children, age 5 to primary school enrollment was surveyed. A qualitative research paradigm was used, which included children's expressions through drawings and narrative ethnographical research.

The research findings indicate that children recognize subjective wellbeing through play and social interactions (friendships and family relationships). They recognize the importance of 
learning as a personal present and long-term benefit. They perceive the ECE setting as a safe place that has appropriate conditions for their residence. Some children emphasize the importance of a sense of security. It is possible to assume that the perception of children in the sample is related to the current epidemiological situation.

Keywords: Subjective wellbeing, play, research with children, friendship.

\section{RESUMEN}

La consideraciones relativas a la niñez van cambiando conforme la sociedad va transformándose y el paradigma social en el que se apoya su conocimiento. En consecuencia, la valoración que se hace de la participación de los niños y las niñas en su crianza ha ido evolucionando hasta quedar definido como un derecho de ellos y ellas a poder expresar sus opiniones; así como, a ser oídas y respetadas.

Esta investigación se centra en comprender la perspectiva infantil en relación con el bienestar subjetivo actual y a largo plazo. Fue aprobada por el Comité de Ética de la Facultad de Formación del Profesorado en Zagreb. Así, fue llevada a cabo de acuerdo con el Código de Ética para la Investigación con Niños (2003) y habiendo obtenido el consentimiento de los niños y niñas participantes y sus padres. Las dimensiones de satisfacción personal, logro social y educativo cobran una gran importancia en este bienestar. Utilizando un cuestionario, se entrevistó a 63 escolares de 5 años pertenecientes a la educación infantil. Se utilizó un paradigma de investigación cualitativa, recogiendo dibujos infantiles de estos escolares, apoyándose, además, en la investigación etnográfica narrativa.

Los resultados de la investigación indican que los niños y niñas reconocen el bienestar subjetivo a través del juego y las interacciones sociales (amistad y relaciones familiares). Consideran, también, la importancia del aprendizaje como un beneficio personal presente y a largo plazo. Perciben el jardín de infancia como un lugar seguro que cuenta con las condiciones adecuadas para su estancia en él. Algunos niños y niñas enfatizan la importancia de sentirse seguros. Es posible asumir que las percepciones infantiles obtenidas con esta muestra están relacionada con la situación epidemiológica actual.

Palabras clave: Amistad, bienestar subjetivo, investigación con niños, juego.

\section{RESUMO}

A compreensão da infância está se modificando com as mudanças no desenvolvimento da sociedade e no paradigma social. Conseqüentemente, muda se a compreensão e a aceitação da criança de sua participação na educação pessoal e formal. O direito da criança se expressar e ter sua opinião levada a consideração é respeitado. Esta pesquisa e focada em compreender a perspectiva das crianças sobre o proprio bem-estar subjetivo atual e de longo prazo. A pesquisa foi aprovada pelo Comitê de Ética da Faculdade de Formação de Professores de Zagreb e realizada de 
acordo com o Código de Ética em Pesquisa com Crianças (2003), com o consentimento das crianças e de seus pais. O bem-estar é considerado nas dimensões de satisfação pessoal e desempenho social e educacional. Foi pesquisada a opinião de 63 crianças com 5 anos de idade até o ensino fundamental utilizando um paradigma de pesquisa qualitativa, que incluiu as expressões das crianças por meio de desenhos e pesquisa etnográfica narrativa. Os resultados da pesquisa indicam que as crianças reconhecem o bem-estar subjetivo por meio de brincadeiras e interações sociais (amizade e relações familiares). Reconhecem tambem a importância da aprendizagem como um benefício pessoal atual e de longo prazo. Elas enxergam o jardim de infância como um local seguro e com condições adequadas para sua estadia. Parte das crianças enfatiza a importância de sensação de segurança. É possível supor que a percepção das crianças que fizeram parte da pesquisa esteja relacionada à situação epidemiológica atual.

Palavras-chave: amizade, bem-estar subjetivo, brincar, pesquisa com crianças.

$\mathrm{T}$ he Convention on the Rights of the Child (UN, 1989, hereafter UNCRC) emphasizes the best interests of the child as a principle by which political and legal decisions and documents concerning children are made. It is possible to problematize how the "best interest" is defined i.e., who defines it. Višnjić-Jevtić, Sadownik and Engdahl (2021) state that this is a concept that most often starts from the perspective of adults. Although this is an approach that should contribute to more respect of children's rights, the adults' perspective as a starting point for the best interests of the child is at odds with children's active participation as a basic idea of the UNCRC (UN, 1989). UNCRC (UN, 1989) sees the child as an equal social subject who has the right to express a personal perspective, to be listened to and respected in relation to decisions made concerning their own lives. The UNCRC signatory countries educational policies are based on the acceptance and integration of the ideas of UNCRC (UN, 1989) within relevant educational documents. Starting from the child's right to participation, it is possible to question the role of children and their perspectives in the creation of these documents. 
Street (2020) states that documents which regulate work in early childhood education (ECE) settings mostly start from the discourse of children's rights emphasizing children's wellbeing as a desired outcome. This approach is visible in the curricula of early and preschool education of different countries, for example Aistear (NCCA, 2009), Te Whariki (Ministry of Education, 2017). In these documents, the wellbeing of children is ensured by the support of ECE settings and ECE professionals. The Croatian National Curriculum for Early and Preschool Education (MZOS, 2015, NKRPOO hereafter) is also aimed at ensuring the wellbeing of children by ensuring a quality environment and teacher competence.

Although education policy emphasizes the wellbeing of children as a key feature of education, it rarely takes into account the children's perspective. The presented research can lead to a greater understanding and respect for children's perspectives on their own wellbeing, as a contribution to the re-construction of the early childhood education curriculum (ECE).

\section{Wellbeing of young children}

Wellbeing is most commonly described as a quality of life (Statham \& Chase, 2010), so it is reasonable to assume that wellbeing varies depending on the age, personal perception, and experiences of the individual. Authors Tatalović Vorkapić and Lončarić (2014) also emphasize that wellbeing is a condition that primarily depends on the perspective of the individual. Ryan and Deci (2001) interpret wellbeing as optimal psychological functioning and experience. These attitudes suggest a connection between the perception of wellbeing and previous experience, and the psychophysical status of the individual. Consequently, there are differences in the wellbeing of children and adults. 
The interpretation of child wellbeing has changed with respect to the child's position in society (Raghavan \& Alexandrova, 2015). Wellbeing in the period of contemporary childhood can be determined starting from the concept of child-centredness, or wellbeing as an outcome of the process of development, upbringing and education in which the child participates and initiates his/her own progress. Croatian NKRPOO (MZOS, 2015) interprets the wellbeing of children as a construct of personal psychophysical wellbeing, optimal social interactions and long-term positive outcomes. Wellbeing is considered through the categories of personal (emotional and physical), social and educational wellbeing of the child. In doing so, personal wellbeing is recognized as a subjective feeling of self-satisfaction (self-confidence and self-esteem), and a feeling of "being good" (being healthy, happy, safe). Social wellbeing is thus understood as the realization of appropriate social interactions, and educational wellbeing as successful, purposeful and socially acceptable development of personal potentials, active learning, creative and constructive action. This understanding can be problematized precisely from the aspect of wellbeing as a personal experience. If wellbeing is considered as a curriculum goal, it is questionable who and in what way assesses the achievement of the goal.

While children's wellbeing may be linked to UNCRC (UN, 1989), it would be wrong to find both concepts (chidren's wellbeing and children's rights) permanently interconnected. Tisdall (2015) distinguishes wellbeing and rights according to two categories: methodology (quantitative/qualitative), and the level of standardization (minimum/maximum). Wellbeing may be documented by drawing on several types of wellbeing indicators (i.e. Bradshaw \& Richardson, 2009) while there are no quantitative indicators for children's rights (Tisdall, 2015). UNCRC (UN, 1989) sets a minimum standard of achieving children's rights, while wellbeing is supposed to have maximum standards. Children's wellbeing and children's rights as concepts seek to provide children with the best possible life, relying on adults to secure or protect them. 
Unfortunately, this gives room for a paradoxical definition of the best interests of the child in relation to their rights and wellbeing. Child participation and decision-making are the basis of children's rights, but when it comes to concepts of wellbeing and children's rights, it is the adults who determine what these concepts should be, without taking into account the children's perspective.

Statham and Chase (2010) state that there are differences in the way children and adults define child wellbeing. Consequently, it is possible for adults to assess how the implementation of the educational process has resulted in wellbeing for children and that the goal of the curriculum has been achieved, without children perceiving the same as wellbeing for them. Acceptance of children as active and competent persons who have the knowledge and ability to understand personal interests and opinions (Bogatić, 2021) indicates the need for more research and respect for their perspective.

\section{Research with children}

Respecting children's perspectives gives us an insight into what children consider important, which is nevertheless particularly important in the context of understanding the goals of the educational process. Unlike the childhood perspective in which the emphasis was on what children cannot yet achieve, or have yet to master, the postmodern image of childhood emphasizes children's abilities and competencies (Halpenny, 2021). This approach enables their active and egalitarian participation in personal development and can be a starting point in the construction of the educational curriculum (Moss, 2014).

Laevers (2015) emphasizes the need for a high focus on a child-centred approach in order to understand children's personal preferences - needs, desires and possibilities. Understanding children's preferences can be achieved through research in which children participate as equal stakeholders (research with children as opposed to research about children). Research with children contributes to understanding 
children's perspectives. Understanding children also affects the theoretical perspective of researchers, while the focus on understanding children's perspectives distances us from assumptions and interpretations of children's statements (Dockett, Einarsdóttir \& Perry, 2019).

In order to truly express their opinion, children need to feel the security and trust that can only be provided by people they know well, primarily practitioners in direct contact. Such an understanding points to a purposeful connection between practitioners as individuals who have built a relationship of trust with children, and scientists who have an objective, scientific approach (Lundy, 2007). The author Lundy (2007) recommends a model based on the UNCRC article (UN, 1989, Art. 12) for the implementation of research with children, which guarantees children the right to receive due attention from adults in all situations relevant to them. Lundy (2007) considers that:

Children must be given the opportunity to express their personal opinions ("provide space")

1. Children must be given the opportunity to express their views (enable "voice" - expression through all forms of expression acceptable to children)

2. Children must be heard (provide "audience" or active adult listening)

3. Children have the right to be involved - to act according to their attitudes and needs ("influence" appropriate to the possibilities).

In order to enable children's freedom of expression, all forms of expression are encouraged (verbal, visual, musical, movement expression...), individually, in pairs or groups, and audio-visual recordings (Dockett, Einarsdóttir \& Perry, 2019). Children's expressions of opinion and their works are accepted as exact statements that can contribute to a deep understanding of childhood and the educational process. Research with children also raises ethical doubts about the inequality of power and authority, the possible invasion of the child's privacy and the denial of the child's right to 
free participation and withdrawal (Dockett, Einarsdóttir \& Perry, 2019). Einarsdóttir (2011) warns that as important as it is to understand and appreciate a child's perspective, there is a trap of "idealizing" children's participation and respecting their perspective.

The specificity of research with children indicates the need to adhere to high ethical standards. The Republic of Croatia has developed a Code of Ethics for Research with Children (2003), which sets out general principles for the protection of the child's wellbeing, integrity and dignity, respect for privacy and anonymity, and general preconditions for conducting research. The child's rights to express opinions and selfdetermination are emphasized. The consent of the child and the parents, and the institution, are prerequisites for the research. Research must be tailored to the child's age, psychophysical status and contextual conditions. The circumstances of the research must guarantee the safety of children.

\section{Method}

Starting from the postmodern image of the child as a (co) creator of their own upbringing and education, it was justified to explore their perspective on wellbeing. The aim of the research was to determine children's perspective on wellbeing, their role and the (possible) role of adults in achieving it. The children's perspective was explored through children's visual and verbal expression. Verbal expression was recorded through narrative ethnographical research, which was stimulated by artistic expression. Data was collected (children's statements and works) during the educational process in collaboration with teachers in the group that children attend. Consent for the research was given by the Ethics Committee of the Faculty of Teacher Education, University of Zagreb. 


\section{Participants}

To explore children's perspectives, research was conducted with children attending ECE settings. Following the specific methodology of research with children, the sample included only those children who were willing to participate in the research and whose parents/guardians consented to participate in the research.

The sample included 63 children, of which there were 34 girls and 29 boys. There are two pairs of twins in the sample. The chronological age of the children in the sample was 68.75 months, ranging from 52 to 83 months. In addition to the children's age, their family status (family structure), and parental involvement in the educational process in ECE settings were also investigated. The sample included 15 children (one child families), 33 families with two children, 11 families with three children, 1 family with 4 , and one with 5 children. One child lives in the family with a biological mother and stepfather, one child has divorced parents ("I live a little at my mom's, and a little at my dad's"), and one child lives in a foster family.

\section{Procedure}

A qualitative research paradigm was used, which included children's expressions through drawings and narrative ethnographical research. The research was conducted in eight ECE settings (four urban ECE settings and four rural ECE settings) in Croatia, whose founders are local self-government units. Chosen ECE settings have a history of positive cooperation with researchers.

Parents were informed about the main goal and steps of the research in order to obtain a clearly informed permission. Interviews with children were conducted when children showed interest in participating.

The research started in September 2020. Due to current epidemiological measures (Covid-19 virus pandemic and specific situations in some ECE settings), the research 
was conducted according to the capabilities of teachers-researchers and the availability of individual children, with the written consent of the institution and of the parents.

\section{Children as Researchers}

A research protocol was compiled that included a customized vocabulary for communicating abstract concepts (wellbeing). Following the aim of the research, teachers talk to children about their perception of wellbeing and ask them to draw concepts highlighted through conversation. Children's drawings were used as a participatory tool in research (Roberts-Holmes, 2011). Topics of conversation before children's artistic expression are related to the feeling of personal satisfaction (what makes them happy, when are they happy), satisfaction with social actors (family, peers) and satisfaction in ECE settings. A similar definition of wellbeing was used in the Thoilliez (2011) study to explain the notion of wellbeing in a way adapted for children. After the artistic expression, the conversation is based on the children's narratives what is drawn.

Conversations with children were recorded with the child's consent (e.g. This conversation is very important, do you agree that I record it?). Since teachers often keep ethnographic notes during the work, children are familiar with this way of documenting. The responses were coded according to the interpretation of wellbeing given in the NKRPOO (MZOS, 2015), but the category of long-term wellbeing was added to the existing categories (Table 1). In total 67 art works were collected, which the children supported with verbal interpretations. 
Table 1

Coding children's perspective

WELLBEING
Examples of children's narratives and artistic responses
Personal, emotional and physical wellbeing of a child as a subjective feeling of self-satisfaction (self-confidence and self-esteem) and feeling good (being healthy, happy, safe)

Social wellbeing as the realization of appropriate social interactions (entering into and maintaining purposeful relationships, understanding and accepting diversity, behaviours appropriate to community culture / socially acceptable behaviours)

Educational wellbeing as successful, purposeful and socially acceptable development of personal potentials (cognitive, artistic, motor...), active learning (research, questioning assumptions, critical analysis, meta cognition as a process of awareness of personal cognition), constructive and creative action

Long-term wellbeing
I adore swimming in the sea.

I love the most when I celebrate a birthday.

I love opening presents - you know that shiny paper.

In ECE settings, I can decide for myself with what (i.e. toy) I will play.

I also like to play in ECE settings, especially with my best friend.

I am happiest because my mom gave birth to my sister.

I like it best when mom and dad are fooling around so we laugh.

A friend always helps me take out the paper to wipe my hands in the bathroom because sometimes I can't do it alone.

I learned how to play in ECE settings; I didn't know that at home alone.

It's not OK to argue. In ECE settings, I learned to negotiate and reconcile.

When I'm as big as dad, I'll be a fisherman too.

I love fixing cars; I'll be a fixer.

\section{Results and Discussion}

Most children relate the meaning of personal and social wellbeing. They are happiest while playing ( $\mathrm{N}=37,58.7 \%$ ), with only two children stating independent play (i.e. playstation). Only one girl states that she is "happy when others are happy", while two children associate their happiness with the happiness and satisfaction of their parents.

Play is the most important activity, with 25 children emphasizing the importance of 
playing with friends, 5 children like to play with siblings, and 4 children with the whole family. They also recognize the importance of friendship as personal emotional wellbeing ("Friends are important for happiness. If someone is sad, you play with them and they are no longer sad."). Only three children in the sample associate personal happiness and contentment with material goods: new toys, stickers, and "something mom buys."

18 children emphasize 'staying in early childhood settings' as personal wellbeing - in ECE settings they are happy, play, celebrate birthdays (2 children), learn (14 children), while 17 children recognize 'staying in early childhood settings' as educational wellbeing. In ECE settings, they learn to paint, write, sing, play and "be good" and "do anything". The most important reason to stay in ECE settings is to play ("You can decide for yourself what to play"), especially playing with friends. Some children also recognize ECE settings as a place for the development of social competencies ("In ECE settings, I learned to negotiate and reconcile if we quarrel a little.").

More than half of the children in the sample $(\mathrm{N}=36,57.1 \%)$ recognize the family as personal and social wellbeing. They state that they are happy in various family interactions. Most children ( $\mathrm{N}=19)$ emphasize the importance of family time together (socializing, trips, walks) (Figure 1.). This is supported by the statements: "I like it best when we all laugh together" and "I am happiest when mom and dad do not have so much work so we can be happy together". Some children differentiate activities with their parents, so 6 boys state that they like to spend time with their father (they do something together), and 4 girls want to be with their mother. A child, whose parents are divorced, emphasizes playing with both parents individually ("I play football with my dad; I mostly build Lego with my mom"). Three children emphasize the importance of family support, of which one boy singles out family cheering (at a sporting event), when he helps his brother and when they help him. Only one child states that "without mom and dad, I am sometimes a little sad ". One child (one-child family) concludes that "it is 
better for me in ECE settings than at home because there is someone to play with in ECE settings" (i.e. Figure 2.). Two children list members of the extended family as one of the predictors of wellbeing ("I like to hug, and my grandmother's house is close", "If mom and dad do not come - then grandma comes to pick me up in ECE settings").

It is evident that children emphasize the social environment as a precondition for their wellbeing, while valuing peer and family support equally. Earlier research (e.g., Sabolova, Birdsey, Stuart-Hamilton \& Cousins, 2020) also highlights the importance of supportive family relationships and peers for creating a subjective sense of wellbeing. Thoilliez (2011) states that children from Western cultures primarily interpret wellbeing through family relationships. Although the research was conducted in the context of an educational institution that could influence the emphasis on the importance of ECE settings and peers as prerequisites for wellbeing, children equally emphasized the importance of family relationships for their sense of satisfaction and happiness. Given that humans are social beings, it is possible to conclude that overall social capital is important for a sense of wellbeing from an early age. It is precisely the (satisfied) need to connect with others that is one of the characteristics of subjective wellbeing (Ryan \& Deci, 2001). Contrary to the importance afforded to children's rights, UNCRC does not mention love or friendship (Tisdall 2015) as things that matter to children. Although almost half of the participants from rural areas participated in the Kurniawati and Hong (2015) study, the research findings did not confirm that children from rural areas experience wellbeing primarily through material resources.

As a predictor of personal wellbeing, children cite "safety" - they are safe in ECE settings and in the family. Feelings of security are contributed by parents $(N=7)$, friends who "defend you" ( $\mathrm{N}=5)$ and "having a home" ("It is very important to have a house"). In the context of the recent earthquake in Croatia, one child states that the most important thing is "to have a family and a house and not to have an earthquake". In ECE settings, they feel safe ("In ECE settings, I'm sure no one will steal me") to 
which teachers also contribute. They recognize the role of the teacher both as a teammate and as a teacher. Unfortunately, the current epidemiological situation has not spared the children either "I feel the worst when it's Corona virus, so I can't go to ECE settings ... because I really like being in ECE settings." and "maybe I'll be a teacher in ECE settings when I grow up". One girl (6.5 years old) draws her wish, "I want this Corona to stop.... If I could change something, I would make Corona disappear". The research was conducted during a partial lockdown, so it is possible that the children's experience of safety is conditioned by the absence of social contacts in a normal environment. Research on the subjective wellbeing of children (Ajduković, Rajhvajn Bulat, Sušac \& Vejmelka, 2020) shows that primary school children feel most secure at home, and much less at school or in the neighborhood. As the age of the children who participated in this study is younger, it is possible that family safety and ECE settings arise from trust in adults. UNCRC (UN, 1989) seeks to ensure the safety of children through protection rights, especially in the family environment. However, the family isn't always a secure and caring place for children. Sometimes, families nurture the culture of society which can be toxic for children (i.e. child brides). So, it is hard to imagine that children live in a family (their best interest), while families (and even societies) have their own "translation" of the best interest of child.

No association was observed between family structure and individual assessments of children except for caring habits. Children in families with more children express satisfaction with playing with siblings. Older children state that they "help the little ones", and younger children recognize the help of the older ones. However, some children estimate that the older brother or sister "does not always have time to play". These findings may be partly related to the current situation. It is possible that due to the pandemic, the children were absent from the ECE settings for some time, so they spent time playing with siblings. 
The long-term wellbeing of the children in the sample is recognized as social and educational wellbeing. The seven children explicitly emphasize that they do not want to lose friends in the future. They understand that they will (perhaps) attend different schools, but they do not perceive (possible) social distance as an obstacle: "I know that we will go to different schools, but we will somehow manage", "I would not survive without friends". Mashford-Scott, Church and Taylor (2012) state that the perception of wellbeing is most often associated with behaviours that contribute (e.g. social skills) or promote wellbeing. Given the importance of the social relationships that emerge from this research, social skills can contribute to making an individual feel satisfaction or feel wellbeing. However, social skills alone will not result in benefits if there is no opportunity for them to manifest. The sample also included 1 child (boy) placed in a foster family who sees his mother once a week. The child draws a rainbow repeatedly. He emphasizes that he is "happiest when he is with a real mother". He states that he will surely change his friends because "when he grows up, he will live with his real mother, so he will no longer see the children from ECE settings".

The children in the sample recognize the importance of formal education, so 6 children emphasize that in ECE settings they are "preparing for school", while sixteen of them (25.4\%) state future occupations. They plan to be teachers (2), car mechanics (2), builders (2), hairdressers (2), firefighters, preschool teachers (2), veterinarians, fishermen, and farmers. Some of the children identify with their parents: "I will drive a truck like my dad.". They assess personal predispositions for certain occupations in an interesting way, for example "I'm not afraid of dentists, so I could be a good dentist and help children". Long-term wellbeing is the desired direction of research into children's experiences of wellbeing. Mashford-Scott, Church and Taylor (2012) state that it is wrong to assess child's wellbeing as an immediate achievement, and that it should be viewed as a lifelong process. The findings of this research show that children themselves do not associate wellbeing with immediate achievement but as continuity 
(play, relationships). Pranoto and Hong (2020) also state that play is a significant predictor of satisfaction, which may be related to children's current and long-term wellbeing. Both play and education are highlighted in UNCRC (UN, 1989) as a crucial part of children's rights. Corominas, González-Carrasco and Casas (2021) stated that even if children have the right to play as one of their fundamental rights, social inequality affects this possibility and thus their wellbeing.

According to the teacher's assessment, the majority of parents $(53.9 \%, N=34)$ adequately cooperate and participate in the educational process in ECE settings. Parents of 23 children (36.5\%) show extremely high engagement for participation in the educational process, while 6 children $(9.5 \%)$ have mostly uninvolved parents (do not show interest). No significant difference in parental involvement of families with one or two children was observed. For example, the majority of parents in a family with only 1 child (66.6\%, N = 10) cooperate appropriately, 3 children (20\%) have highly engaged parents, and 2 children (13.3\%) have non-engaged parents. In a family with two children, $72.7 \%$ of parents cooperate appropriately, while $15 \%$ are highly engaged. Teachers estimate that in families with three or more children, a larger number of parents are highly interested in participating in the educational process ( $N=8,53.3 \%)$, and only two of them are extremely uninterested. These results may indicate that parents with more collaborative experience can better understand expectations from ECE settings and are therefore more engaged. It is also possible that they have developed relationships with teachers, so teachers themselves assess them as more engaged. Assessing parental involvement may vary depending on the perception of an individual teacher, so it is possible that what some have rated as high engagement, others have assessed as appropriate collaboration. Due to the lack of similar research, it is not possible to triangulate the results with other research in this section. 


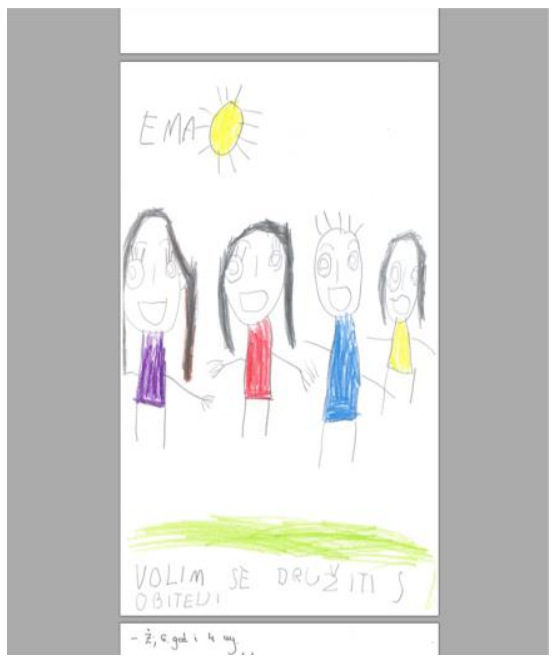

Figure 1. "I like to hang out with my family" (boy, 6.2 years old)

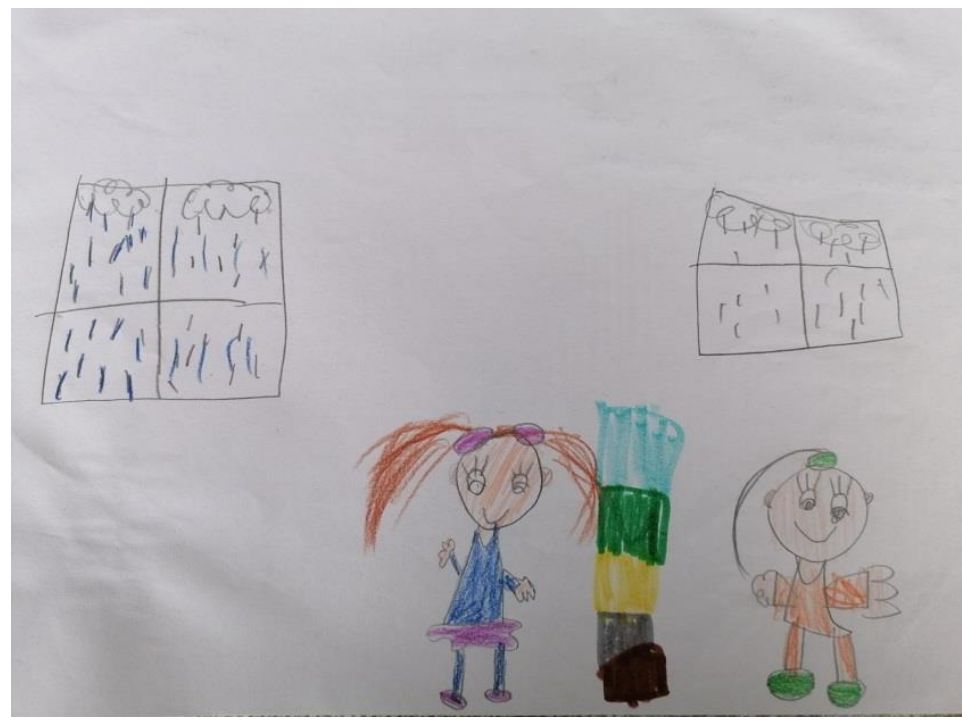

Figure 2. "I like going to ECE settings because I can play with friends while it's raining outside" (girl, 5.8 years old)

Mekonen and Tiruneh (2014) correlated implementation of the UNCRC (UN, 1989) with children's wellbeing and found many differences (and difficulties) in its implementation, caused by several factors which influence the level of children's wellbeing. However, the same authors stated that regardless of possible insufficient support of children's wellbeing, the Convention (UN, 1989) puts children on policy agendas all over the world. 


\section{Conclusion}

The findings of this research represent a child's subjective experience of personal wellbeing. Wellbeing is a highly conditioned subjective experience that is difficult to quantify. Research has shown that children assess social wellbeing most significantly. They associate personal and educational wellbeing with playing, which most often takes place in a social environment. It is therefore possible to conclude that they link both personal and educational wellbeing to social wellbeing. Children were the least likely to highlight situations and activities that could be related to personal wellbeing. With their statements, they showed how they connect wellbeing with events that make them happy (for example, celebrating a birthday or Christmas) and with security.

The possible limitation of this research is in the sample size and the conditions in which it was conducted. It is reasonable to assume that children came into contact with other children during the research and influenced each other's statements. Research with children is an important segment of insights into children's perspectives, but it is questionable how many researchers are willing to hear and record children's reflections without trying to add their own interpretation to them. The period in which the study was conducted (epidemiological measures due to the pandemic, partial lockdown) may have influenced the children's experiences described in this research. The presented research provides insight into children's own perception of wellbeing. A comparison of children's statements with the wellbeing described in the NKRPOO (MZOS, 2015) points to the need for its revision, with a clearer emphasis on play and the social environment as the primary features of child's wellbeing.

UNCRC (UN, 1989) should be considered as a foundation for achieving children's wellbeing, by respecting four general principles (best interest of the child, protection, non-discrimination, and participation) stated in the UNCRC (UN, 1989). Adults should constantly work on maximizing the potential for children's wellbeing. Even though children's best interest is one of the UNCRC (UN, 1989) pillars, the world is still 
witnessing a lack of health care, education and even play for many children. State parties should ensure continuity of monitoring the realization of those interests. Otherwise, UNCRC (UN, 1989) remains a recommendation without legal consequences for non-compliance of children's rights.

\section{References}

Ajduković, M., Rajhvajn Bulat, L., Sušac, N., \& Vejmelka, L. (2020). Subjektivna dobrobit djece u Hrvatskoj. Zagreb: Ured UNICEF-a za Hrvatsku. https://www.unicef.org/croatia/media/5136/file/Subjektivna\%20dobrobit\%20djec e\%20u\%20Hrvatskoj.pdf

Bradshaw, J., \& Richardson, D. (2009). An index of child well-being in Europe. Child Indicators Research, 2(3), 319-351.

Bogatić, K. (2021). Children as active participants in a collaborative relationship between family and the early and preschool education institution. In A. Višnjić Jevtić \& I. Visković (Eds.), Challenges of collaboration: Development of teachers' professional competences for collaboration and partnership with parents (pp. 67-76). Zagreb: Alfa.

Corominas, M., González-Carrasco, M., \& Casas, F. (2021). Analyzing factors for an optimum play environment through children's subjective well-being indicators. Children and Youth Services Review, 122, 105688.

Dockett, S., Einarsdóttir, J., \& Perry, B. (2019). Listening to Children's Advice about Starting School and School Age Care. London: Routledge.

Einarsdóttir, J. (2011). Icelandic children's transition experiences. Early Education and Development, 22(5), 737-756. https://doi.org/10.1080/10409289.2011.597027

Etički kodeks istraživanja s djecom [Code of Ethics for Research with Children]. (2003). Vijeće za djecu Republike Hrvatske, Državni zavod za zaštitu obitelji, materinstva i mladeži. https://mef.unizg.hr/wp-content/uploads/2015/06/Eticki- 
kodeks-istrazivanja-s-

djecom.pdf?rs_file_key=6512300855eef44cabde13028337755

Halpenny, A. M. (2021). Capturing Children's Meanings in Early Childhood Research and Practice: A Practical Guide. Routledge.

Kurniawati, Y., \& Hong, J. Z. (2015). May I have some more time to play, please?: An exploration of Javanese Indonesian children's happiness. Research on Humanities and Social Sciences, 5(12), 69-74.

Laevers, F. (2015). Making care and education more effective through wellbeing and involvement. An introduction to Experiential Education. Research Centre for Experiential Education, University of Leuven: Leauven, Belgium.

Lundy, L. (2007). 'Voice'is not enough: conceptualising Article 12 of the United Nations Convention on the Rights of the Child. British educational research journal, 33(6), 927-942.

Mashford-Scott, A., Church, A., \& Tayler, C. (2012). Seeking children's perspectives on their wellbeing in early childhood settings. International Journal of Early Childhood, 44(3), 231-247.

Mekonen, Y., \& Tiruneh, M. (2014). Implementation of the convention on the rights of the child and its effect on child well-being. In Ben-Arieh, A., Casas, F., Frønes, I., Korbin, J. (Eds.), Handbook of child well-being: Theories, methods and policies in global perspective (pp. 2463-2502). Springer.

Ministarstvo znanosti, obrazovanja i sporta [MZSO] (2015). Nacionalni kurikulum ranog i predškolskog odgoja i obrazovanja. Zagreb: Ministarstvo znanosti, obrazovanja i sporta Republike Hrvatske.

Ministry of Education (2017). Te Whariki: Early Childhood Curriculum. Wellington: Ministry of Education, New Zealand.

Moss, P. (2014). Transformative change and real utopias in early childhood education: A story of democracy, experimentation and potentiality. Routledge. 
National Council for Curriculum and Assessment [NCCA] (2009). Aistear: The Early Childhood Curriculum Framework. Dublin: National Council for Curriculum and Assessment

Pranoto, Y. K. S., \& Hong, J. (2020). Young Children Voices of Happiness: Learning from Urban Area in Indonesia. Asia-Pacific Journal of Research in Early Childhood Education, 14(3) pp. 139-164. http://dx.doi.org/10.17206/apjrece.2020.14.3.139

Raghavan, R., \& Alexandrova, A. (2015). Toward a theory of child wellbeing. Social Indicators Research, 121(3), 887-902.

Roberts-Holmes, G. (2011). Doing your early years research project: A step-by-step guide. SAGE

Ryan, R.M., \& Deci, E.L. (2001). On happiness and human potentials: A review of researc on hedonic and eudaimonic wll-being. Annual revierw of psychology, $52(1), 141-166$.

Sabolova, K., Birdsey, N., Stuart-Hamilton, I., \& Cousins, A. L. (2020). A cross-cultural exploration of children's perceptions of wellbeing: Understanding protective and risk factors. Children and Youth Services Review, 110, 104771.

Statham, J., \& Chase, E. (2010). Childhood wellbeing: A brief overview. Loughborough: Childhood Wellbeing Research Centre.

Street, M. (2020). Theorising child wellbeing: Towards a framework for analysing Early Childhood Education policy in England. Journal of Early Childhood Research, https://doi.org/10.1177/1476718X20969841.

Tatalović Vorkapić, S., \& Lončarić, D. (2014). Validacija hrvatske verzije ljestvice socioemocionalne dobrobiti i otpornosti predškolske djece. Hrvatska revija za rehabilitacijska istraživanja, 50 (2), 102-117.

Thoilliez, B. (2011). How to grow up happy: An exploratory study on the meaning of happiness from children's voices. Child Indicators Research, 4(2), 323-351. 
United Nations [UN]. (1989). Convention on the rights of the child. General assembly. https://www.ohchr.org/en/professionalinterest/pages/crc.aspx

Tisdall, E. K. M. (2015). Children's Rights and Children's Wellbeing: Equivalent Policy Concepts?. Journal of Social Policy, 44(04), 807823. https://doi.org/10.1017/s0047279415000306

Višnjić-Jevtić, A., Sadownik, A. R., \& Engdahl, I. (2021). Broadening the rights of children in the Anthropocene. In A. Višnjić-Jevtić, A. R. Sadownik \& I. Engdahl (Eds.), Young children in the world and their rights: Thirty years with the United Nations Convention on the Rights of the Child (237-273). London: Springer

\section{Authors' contribution statement}

Both authors equally contributed to design and implementation research, as well as to the analysis the results and writing of the manuscript.

\section{Editor de sección}

Las editoras de sección de este artículo fueron Magali Reis y Mariela Losso.

ORCID ID: 0000-0001-6741-1638

ORCID ID: 0000-0001-7395-1163

\section{Formato de citación}

Visnjic-Jevtic, A. \& Visković, I. (2021). What about Us? - Children's Perspectives on their Wellbeing. Psicología, Conocimiento y Sociedad, 11(1), 57-78. doi: http://dx.doi.org/10.26864/PCS.v11.n1.3 